\title{
Forest Transformation Following European Settlement in the Saguenay-Lac-St-Jean Valley in Eastern Québec, Canada
}

\author{
Sébastien Dupuis ${ }^{1}$, Victor Danneyrolles ${ }^{1}$, Jason Laflamme ${ }^{2}$, Yan Boucher $^{3}$ and \\ Dominique Arseneault ${ }^{1 *}$
}

'Département de Biologie, Chimie et Géographie, Centre d'Études de la Forêt and Chaire de Recherche sur la Forêt Habitée, Université du Québec à Rimouski, Rimouski, QC, Canada, ${ }^{2}$ Direction des Inventaires Forestiers, Ministère des Forêts, de la Faune et des Parcs du Québec, Québec, QC, Canada, ${ }^{3}$ Direction de la Recherche Forestière, Ministère des Forêts, de la Faune et des Parcs du Québec, Québec, QC, Canada

\section{OPEN ACCESS}

Edited by: Tuomas Aakala

University of Helsinki, Finland

Reviewed by:

Mary E. Edwards,

University of Southampton,

United Kingdom

Albert Eugene Fulton, University of North Alabama

United States

${ }^{*}$ Correspondence:

Dominique Arseneault dominique_arseneault@uqar.ca

Specialty section:

This article was submitted to

Paleoecology,

a section of the journal

Frontiers in Ecology and Evolution

Received: 31 March 2020

Accepted: 14 July 2020

Published: 05 August 2020

Citation:

Dupuis S, Danneyrolles V.

Laflamme J, Boucher Y and

Arseneault D (2020) Forest

Transformation Following European

Settlement

in the Saguenay-Lac-St-Jean Valley

in Eastern Québec, Canada.

Front. Ecol. Evol. 8:257.

doi: 10.3389/fevo.2020.00257
Human activities have changed forest composition of northeastern North America since European settlement by increasing the importance of pioneer shade-intolerant species, at the expense of shade-tolerant and long-lived species. This study used tree taxa lists from land survey archives (1842-1935) to document the pre-settlement forest composition in a heavily transformed region at the temperate-boreal interface in eastern Québec (Canada). Pre-settlement forests were dominated by a spruce-fir-white birch assemblage. Two additional assemblages were characterized by high relative frequency of the fire-adapted jack pine and poplar, suggesting that fire was an important factor of pre-settlement forest dynamics. Comparison with modern forest inventories (19802010) showed that trembling aspen, jack pine and red maple increased to the detriment of spruce, yellow birch, and white and red pines. The spruce-fir-white birch assemblage is now confined to high elevations and steep slopes, while the jack pine assemblage has extended its distribution and strengthen its association with sandy deposits. Surveyors' fire observations revealed a high fire activity during the settlement period (1842-1971) and human ignitions were probably the predominant cause. While settlement fires are a likely explanation for the post-settlement increase of jack pine and trembling aspen, industrial logging and land clearing are important factors that could explain the decline of spruce and pines (red and white). Ecosystem-based forest management should aim to increase spruce frequency and dominance over disturbance-adapted (shade intolerant and fast-growing) species, and to restore yellow birch, cedar, white, and red pines in the plains sector where forest transformation has been the most important.

Keywords: anthropogenic fires, temperate-boreal ecotone, land survey records, forest composition change, landuse change, poplar, spruce

\section{INTRODUCTION}

Forests of northeastern North America have undergone major transformations since European settlement. During the 19th and 20th centuries, deforestation for agriculture, fire escapes from settlements and subsequent fire suppression, industrial logging and urbanization have modified the natural disturbance regimes (Whitney, 1994; Lorimer, 2001; Nowacki and Abrams, 2008). 
As a result, modern forest landscapes are younger, more fragmented and homogenized, and composed of an increased proportion of early-successional species compare to presettlement times (Foster et al., 1998; Schulte et al., 2007; Boucher et al., 2009; Thompson et al., 2013; Terrail et al., 2019). Although climate change has also influenced forest composition during that period (Fisichelli et al., 2014; Pederson et al., 2015; BoisvertMarsh et al., 2019), the impact of anthropogenic activities was stronger or more prevalent in several regions (Nowacki and Abrams, 2015; Danneyrolles et al., 2019), such as the temperateboreal ecotone (Brice et al., 2019, 2020).

Knowledge of forest composition and natural disturbances prior to European settlement can provide targets for ecosystembased management and restoration of forest ecosystems (Landres et al., 1999; Gauthier et al., 2009). This is particularly important in heavily transformed regions where unmanaged forests no longer exist. While our ability to reduce gaps between pre-settlement and modern forest composition could become unrealistic under severe climate forcing (Boulanger et al., 2019), understanding how forests have been transformed by human activities can help make forests more resilient to future disturbances and climate change (Millar and Stephenson, 2015; Johnstone et al., 2016) as well as to restore functional targets. For example, growth rate, longevity and shade tolerance of pre-settlement species could be considered, regardless of strict species identity, in order to maintain or restore ecosystem function.

Land survey records are a reliable source of data to evaluate changes in forest composition since pre-settlement (Schulte and Mladenoff, 2001; Terrail et al., 2014). Several studies have documented changes in frequency and dominance of individual taxa at different spatial scales by comparisons with modern inventories (e.g., Friedman and Reich, 2005; Dupuis et al., 2011; Thompson et al., 2013), and have shown that taxa assemblages also responded to environmental gradients (e.g., elevation, surface deposits) and disturbances (White and Mladenoff, 1994; Schulte et al., 2007; Danneyrolles et al., 2016, 2018; Terrail et al., 2019; Thomas-Van Gundy et al., 2020).

In the northern part of the temperate zone, forests were historically dominated by late-successional and long-lived conifers, particularly spruces (Picea glauca and Picea mariana), balsam fir (Abies balsamea), white cedar (Thuja occidentalis), and pines (Pinus strobus and Pinus resinosa), along with deciduous companion species like maples (Acer spp.) and yellow birch (Betula alleghaniensis) (Lorimer, 1977; Jackson et al., 2000; Dupuis et al., 2011; Terrail et al., 2019). Sectors where fires were more frequent included a larger component of pines (notably jack pine, Pinus banksiana), poplars (Populus tremuloïdes and Populus balsamifera) and white birch (Betula papyrifera) (Pinto et al., 2008; Hanberry et al., 2013; Danneyrolles et al., 2016; Marchais et al., 2020). The most noticeable vegetation change since presettlement is the general expansion of early-successional and fast-growing species such as poplars, maples, and white birch to the detriment of conifers (Friedman and Reich, 2005; Pinto et al., 2008; Danneyrolles et al., 2016; Terrail et al., 2019; Marchais et al., 2020). However, only a few studies have used land survey records to evaluate forest composition changes in the temperateboreal ecotone in Ontario (Pinto et al., 2008) and western Québec
(Danneyrolles et al., 2016; Marchais et al., 2020), and none in eastern Québec.

Located at the ecotone between temperate and boreal forests in eastern Québec, the Saguenay-Lac-St-Jean valley (hereafter SLSTJ) has experienced rapid colonization since the mid-19th century, resulting in the clearing of large areas of forest for agriculture in parallel with numerous human-induced fires (Girard and Perron, 1989; Boucher et al., 2014). The region has also been extensively exploited by the forest industry, such that unmanaged forests are now small and scarce. While fire had a relatively minor role in disturbance regime in temperate forests of eastern Québec and northeastern United States just before European settlement (Lorimer, 1977; Fortin, 2018; Terrail et al., 2019), the SLSTJ probably experienced higher fire activity due to its location at the very southern fringe of the boreal biome, which is characterized by higher fire activity than the temperate forest (Erni et al., 2020).

Although land survey archives are available throughout SLSTJ in the form of tree taxon lists, which are ranked tree taxa enumerations along survey lines (Dupuis et al., 2011; Terrail et al., 2014), this data source has not been exploited yet. Accordingly, the objectives of this study were to (1) document the presettlement forest composition of SLSTJ at both regional and landscape scales, (2) assess changes through comparison with modern forest inventories, while paying special attention to settlement fires and environmental gradients, and (3) discuss how this new knowledge can be used to plan forest management in the temperate-boreal ecotone.

\section{Study Area}

The study area $\left(19,400 \mathrm{~km}^{2}\right)$ is located in eastern Québec, between $69^{\circ} 18^{\prime}$ and $72^{\circ} 59^{\prime} \mathrm{W}$ and $47^{\circ} 47^{\prime}$ and $49^{\circ} 15^{\prime} \mathrm{N}$ (Figure 1). It is situated within the Saguenay-Lac-St-Jean valley, a depression in the eastern rim of the Canadian Shield (Robitaille and Saucier, 1998). According to the provincial vegetation classification, the Saguenay Lac-St-Jean plains and the low hills surrounding both Saguenay and St. Lawrence Rivers correspond to mixed temperate forests, whereas boreal mixedwood forests dominate the more elevated outer edge of the study area (Robitaille and Saucier, 1998). The natural disturbance regime is characterized by low intensity outbreaks of spruce budworm (Choristoneura fumiferana) (Blais, 1983; Simard et al., 2006), and fires (Boucher et al., 2014; Pilon and Payette, 2015). Fertile agricultural lands are present in the lowlands where clay deposits left by the postglacial Laflamme Sea (Elson, 1969) mix with sandy and organic deposits, while glacial tills and rocky outcrops are the main surface deposits on the uplands (Robitaille and Saucier, 1998). Annual mean temperature and precipitations (1981-2010) range from 0.8 to $3.4^{\circ} \mathrm{C}$ and from 833 to $1180 \mathrm{~mm}$ (with $24-35 \%$ as snow), respectively (Environment Climate Change Canada, 2019).

From the 17th to the early 19th centuries, human activities in the Saguenay Lac-St-Jean valley were related to the fur trade between the hunter-gatherer Innu First Nation and Europeans (Girard and Perron, 1989). Nomadic people have frequented the valley for more than 6,000 years (Langevin and Plourde, 2018) and used its hydrographic network to travel and make exchanges with other First Nations (Girard and Perron, 1989). 


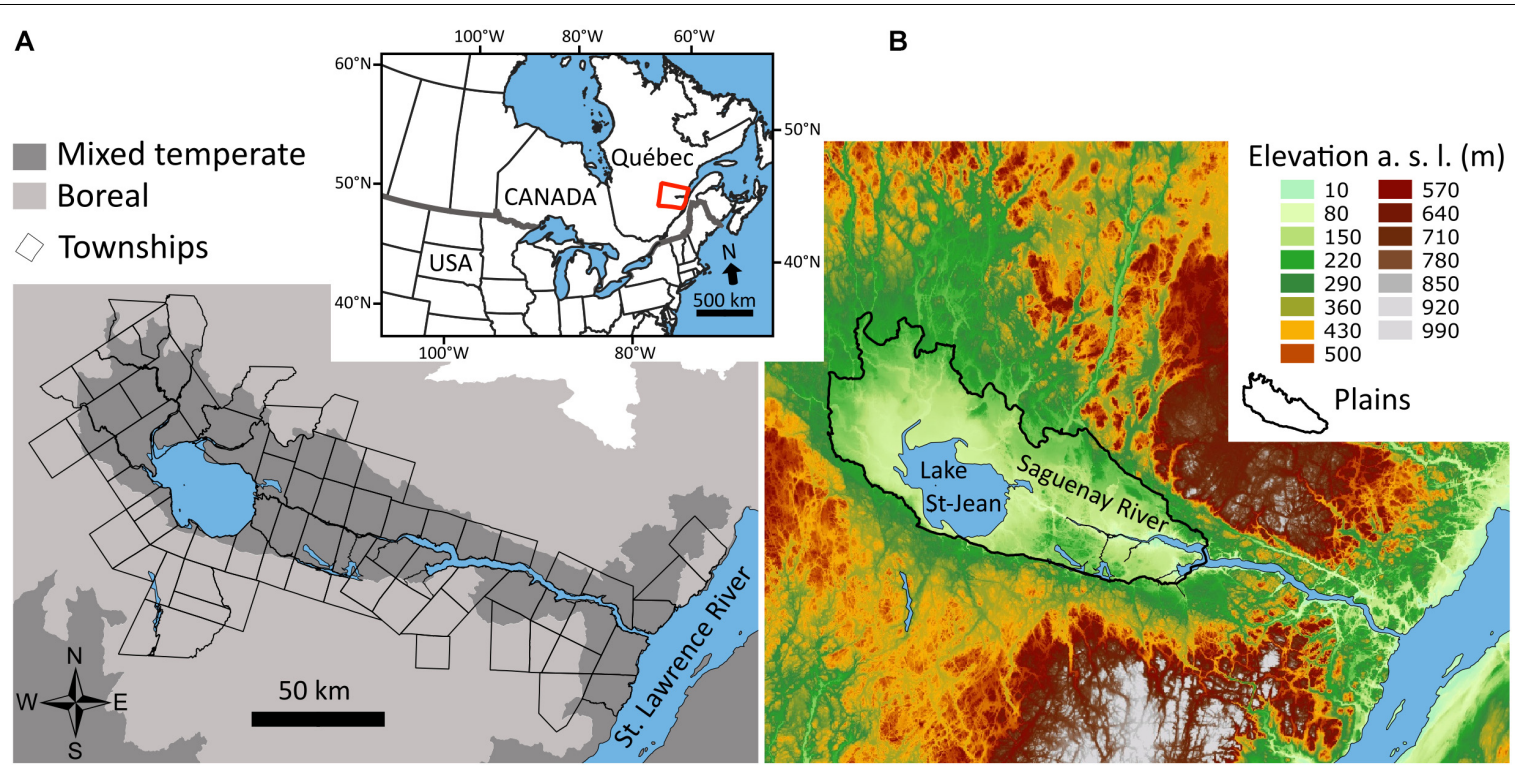

FIGURE 1 | Location of the study area (inset) in eastern Canada, along with maps of townships and vegetation zones (A), and of the elevation bands (metres above sea level) showing the Saguenay-Lac-St-Jean Plains (B).

Even though they may have influenced the fire regime, the land-use practices of these populations and their impact on the regional forest are poorly documented (Oberndorfer, 2020). It was only in 1842 that the region was officially opened to European settlement with the aim of clearing new agricultural land and exploiting forests to supply timber to England (Girard and Perron, 1989). Selective cuttings during the 19th century were directed toward large white pine, red pine and white spruce trees along rivers. Extensive logging began at the turn of the 20th century with the rise of pulp and paper industry targeting conifers (Girard and Perron, 1989). The important river network allowed the construction of several hydroelectric dams and the region experienced an industrial golden age during the 20th century (Girard and Perron, 1989), with the population increasing about tenfold from about 28,800 to 262,500 inhabitants between 1891 and 1961 (Pouyez et al., 1983).

\section{MATERIALS AND METHODS}

\section{Historical and Modern Data}

The reconstruction of pre-settlement forest composition is based on 146 logbooks recording the first subdivision of 74 townships from 1842 to 1935, of which 80\% were surveyed before 1900 . The typical SLSTJ township is a square of $10 \times 10$ miles $(16 \mathrm{~km} \times 16 \mathrm{~km})$ subdivided into parallel ranges of 1 mile $(1.6 \mathrm{~km})$ deep, that are in turn subdivided into lots of 13 chains (1 chain $=20.1 \mathrm{~m}$ ) wide. Observations of forest composition along range lines are mostly taxon lists (e.g., spruce, fir, and white birch) and specific cover types (e.g., spruce stand and cedar stand). General cover types such as "mixed wood" or "hardwood" are infrequent and were not considered in the analyses. We assigned a rank to each taxon listed, assuming that taxa were enumerated according to their relative basal area in the forest stands (Terrail et al., 2014). Specific cover types were considered equivalent to pure stands of the corresponding taxon in order to include them as taxon lists.

In the surveyors' logbooks, each observation comes with a distance in chains from the start of the survey line, or from the last planted post. We classified these observations into two geometric types, points or lines, according to how the surveyors recorded them. Most observations are points, written next to a distance but with no clear beginning or end along the survey line. Points are either regularly or irregularly spaced. Regularly spaced point observations are often made at lot corners or at every 5, 10, or 20 chains $(101,201$, and $402 \mathrm{~m}$ ). Linear observations are also frequent and contain both a start and an end position, generally delineated by lot limits $(260 \mathrm{~m})$. In order to combine points and lines into the same database, both types were weighted according to the size of the corresponding stands along surveyed lines. Each line observation was weighted by its length and each point was weighted by the mean of the distances to the previous and next observations (Dupuis et al., 2011). Weighted observations were used in all calculations involving historical data. Observations were georeferenced as points or lines using modern cadastral maps built from the same land survey records.

Because the occurrence of fires was important in the logbooks reporting the original surveys of townships (see section "Results"), fires mentioned in resurvey mission logbooks were also tallied in order to document the prevalence of forest fires over the entire settlement period. Resurvey missions were required to inspect or correct previous works, and to restore original lines and lot corners that had disappeared over time. To complete the picture, recent fires (1950-2015) were compiled from the Québec government fire database (MFFP). 
The present-day forest composition was assessed using the last three decadal forest inventories (1980-2010) conducted by the Québec government. These inventories are based on circular plots of 0.04 ha, stratified according to the different types of productive forests (Ministère des Forêts, de la Faune et des Parcs secteur des forêts $[\mathrm{MFFP}], 2016)$. Within the plots, all stems $>9 \mathrm{~cm} \mathrm{DBH}$ (diameter at breast height: $1.3 \mathrm{~m}$ ) are tallied by species and $2 \mathrm{~cm} \mathrm{DBH}$ classes, thus allowing calculation of the basal area $\left(\mathrm{m}^{2} \mathrm{ha}^{-1}\right)$ by species. To match the taxa mentioned by surveyors, spruce, maple, poplar, and pine species other than jack pine (listed as "cypress" by surveyors) were grouped at the genus level (i.e., Picea spp., Acer spp., Populus spp., and other pines). In modern plots, all taxa are recorded in all plots, whereas in historical observations less abundant taxa may have been overlooked by surveyors at some sites. Thus, taxa representing less than $5 \%$ of the total basal area of a plot were excluded from the modern dataset so that the average number of taxa per observation is equivalent between the two periods (Supplementary Figure S1). A rank was then assigned to each taxon according to its relative basal area within modern plots. Only modern plots that were located within a maximum distance of $3 \mathrm{~km}$ from the nearest historical observation were retained. In sectors with low density of historical observations, this maximum distance was set to $1 \mathrm{~km}$. Finally, taxa that occurred in less than $3 \%$ of both data sets were grouped as "other."

\section{Data Analyses}

We used three different metrics to describe the regional forest composition for the pre-settlement and modern periods. First, we calculated the frequency of each taxon as the proportion of all observations (weighted length or modern plots) mentioning the corresponding taxon, regardless of its rank in those observations. Second, we calculated a rank frequency $\left(R F_{i r}\right)$ for each taxon occurring in the first four ranking positions (i.e., $r=1,2,3,4$; Scull and Richardson, 2007) using the formula:

$$
R F_{i r}=\left(N_{i r} / M_{r}\right) \times 100,
$$

where $N_{i}$ is the number of observations mentioning the taxon $i$ and $M_{i}$ is the total number of observations. Third, the dominance represents the frequency of occurrence of each taxon $i$ at the first ranking position (i.e., $r=1$ ).

To compare pre-settlement and present-day forest composition at the landscape scale, we divided the study area into a grid of $5 \mathrm{~km} \times 5 \mathrm{~km}$ cells. We first retained cells containing at least four historical observations $(n=579)$, of which we discarded cells containing less than four modern plots (99 cells or $17 \%$, Supplementary Figure S2), resulting in 480 cells with a mean of 42 historical observations and 24 modern plots. Most discarded cells on the plains did not contain enough modern plots due to settlement and low present-day forest cover (Supplementary Figure S2), while the low density of historical observations at the periphery of the study area was the main factor restricting the retention of cells with enough modern plots.

In each cell, and for both periods, we first calculated the frequency of each taxon as the proportion of all observations (weighted length or modern plots) mentioning the corresponding taxon in the grid cell. Then, to facilitate comparisons between taxa and cells, we calculated a relative frequency for each taxon into each cell by scaling its frequency relative to the sum of the frequencies of all taxa. We mapped the relative frequency for each of the 11 retained taxa.

Two subsequent analyses were performed using the grid cells of taxa relative frequency. We first identified landscape tree assemblages for both time periods using a Ward-like hierarchical clustering based on Bray-Curtis dissimilarity index. This clustering method minimizes the number of groups and the intra-group variation (Legendre and Legendre, 2012). The 480 cells from the pre-settlement and modern periods were combined into one dataset and Bray-Curtis dissimilarity was calculated between every pair of cells based on their taxa relative frequency. The clustering was performed in a single run, so that the outcome was one set of clusters for the 960 cells, which allowed a direct comparison of tree assemblages between periods. An optimal number of five clusters was retained in order to minimize the number of clusters while maximizing the proportion of variance explained by the clustering (Supplementary Figure S3).

Second, to visualize compositional changes along environmental gradients, a principal component analysis (PCA) was performed on environmental variables (surface deposits including clay, organic, till, rocks, sand; elevation; slope) for the 480 cells. We also considered a "settlement" variable as a combination of agricultural and urban (including roads) areas. All variables are expressed as percentages of land cover per cell as determined from modern forestry maps (photo-interpretation 2006-2011; 1:20,000 scale; Ministère des Forêts, de la Faune et des Parcs secteur des forêts [MFFP], 2015), except elevation and slope which are means from a TIN (Triangular Irregular Network) built from governmental hypsometric maps (scale 1:20 000 with $10-\mathrm{m}$ contour intervals; Ministère de l'Énergie et des Ressources Naturelles du Québec [MERN], 2007). The PCA was performed on a correlation matrix of the standardized environmental variables. No axes rotation was used to facilitate the interpretation of the data. In order to evaluate the transition of landscape tree assemblages across environmental gradients, each cluster for each period was plotted as the centroid of cell scores of the corresponding cluster on the two principal axes of the PCA. PCA biplots showing environmental variables and cell colors for the clusters of each period are presented in Supplementary Figure S4. Ward's hierarchical clustering and PCA analysis were performed using $\mathrm{R}$ software (R Core Team, 2019 version 3.6.1) using the stats (hclust function) and FactoMineR (PCA function) packages, respectively.

\section{RESULTS}

Fires occurred throughout the study area during the settlement period (Figure 2). Surveyors reported at least one fire in 72 of the 74 townships under study between 1842 and 1971. Fires from resurveys represent $58 \%$ of all fires $(2,164 \mathrm{~km})$, and most of them happened during the 1920 and 1930 decades (Figure 2A). Sectors with no fire reported by surveyors could still have burned because fire compilation maps prior to 1950 (Québec government, not 




shown), which are also incomplete, show several burned areas not mentioned by surveyors. Concerning recent fires, they mostly occurred during the 1950 decade, which account for $79 \%$ of the total area burned between 1950 and 2015 (Figure 2B). Recent fires were mostly concentrated in the northern sector where they overlapped several fires previously recorded by surveyors. The cause of the fires during the 1950-1970 period is unknown, while $90 \%$ of the fires reported between 1970 and 2015 were of human origin.

During the pre-settlement period, spruce, white birch, and balsam fir were the most frequent (58.6-80.4\%) and dominant (12.7-41.5\%) taxa (Table 1), across the study area (Figure 3). Yellow birch, poplar and jack pine were also common with frequency ranging from 21.7 to $17.0 \%$. Poplar displayed a patchy distribution across the grid cells, while jack pine and yellow birch were more prevalent in the northwest and southeast sections, respectively. All remaining taxa were comparatively less frequent and dominant and more locally distributed. The spruce taxon was more frequently mentioned at rank 1 than ranks 2-4, indicating that it tended to be dominant when present. Conversely, balsam fir and white birch tended to be co-dominant as they were mostly listed at positions 2 and 3, respectively (Table 1).

Comparison with modern plots indicated substantial changes in forest composition since pre-settlement time (Table 1 and Figure 3). Poplar and maple showed the most important frequency increases $(+33.3$ and $+14.2 \%$, respectively), while spruce $(-23.1 \%)$ and yellow birch $(-13.8 \%)$ experienced the largest decreases. Concerning dominance, poplar showed by far the largest increase $(+20.7 \%)$, alongside jack pine $(+3.6 \%)$, maple $(+3.2 \%)$ and white birch $(+2.3 \%)$, while spruce and yellow 
TABLE 1 | Taxa frequencies and ranked frequency index $\left(R F_{i r}\right)$ for pre-settlement (1842-1935) and modern (1980-2010) periods.

\begin{tabular}{|c|c|c|c|c|c|c|c|c|c|c|}
\hline \multirow[t]{3}{*}{ Taxa } & \multicolumn{5}{|c|}{$1842-1935(n=22,577)$} & \multicolumn{5}{|c|}{$1980-2010(n=11,828)$} \\
\hline & \multirow{2}{*}{$\begin{array}{c}\text { Frequency } \\
\text { (\%) }\end{array}$} & \multicolumn{4}{|c|}{$R F_{i r}(\%)$} & \multirow{2}{*}{$\begin{array}{c}\text { Frequency } \\
\text { (\%) }\end{array}$} & \multicolumn{4}{|c|}{$R F_{i r}(\%)$} \\
\hline & & 1 & 2 & 3 & 4 & & 1 & 2 & 3 & 4 \\
\hline Spruce & 80.4 & 41.5 & 29.5 & 17.2 & 10.7 & 57.3 & 19.4 & 19.3 & 20.9 & 21.4 \\
\hline White birch & 62.1 & 12.7 & 18.4 & 44.7 & 18.3 & 59.2 & 15.0 & 23.7 & 24.2 & 22.7 \\
\hline Balsam fir & 58.6 & 19.4 & 28.3 & 15.3 & 13.7 & 57.5 & 20.7 & 21.4 & 19.3 & 16.8 \\
\hline Yellow birch & 21.7 & 4.8 & 3.7 & 7.3 & 23.0 & 7.9 & 1.9 & 2.3 & 3.4 & 4.5 \\
\hline Poplar & 19.2 & 3.9 & 6.1 & 5.2 & 13.8 & 52.5 & 24.6 & 16.2 & 13.7 & 13.0 \\
\hline Jack pine & 17.0 & 8.0 & 5.2 & 4.1 & 4.3 & 20.9 & 11.6 & 6.1 & 4.0 & 3.0 \\
\hline Other pines & 10.5 & 2.6 & 1.5 & 2.3 & 5.8 & 1.8 & 0.2 & 0.6 & 0.9 & 1.0 \\
\hline Larch & 9.7 & 3.7 & 5.0 & 0.9 & 2.1 & 4.3 & 1.0 & 1.9 & 1.8 & 1.1 \\
\hline White cedar & 8.1 & 1.9 & 0.9 & 1.3 & 3.6 & 4.9 & 1.1 & 1.4 & 1.9 & 2.8 \\
\hline Ash & 3.9 & 0.8 & 0.5 & 0.6 & 1.7 & 3.3 & 0.9 & 1.1 & 1.4 & 1.8 \\
\hline Maple & 2.8 & 0.4 & 0.5 & 0.5 & 1.2 & 17.0 & 3.6 & 5.4 & 7.2 & 9.7 \\
\hline Other & 3.5 & 0.2 & 0.4 & 0.4 & 1.8 & 2.6 & 0.2 & 0.7 & 1.5 & 2.1 \\
\hline Total & & 100 & 100 & 100 & 100 & & 100 & 100 & 100 & 100 \\
\hline
\end{tabular}

The dominance index corresponds to $R F_{i r}=1$.

birch declined by 22.1 and $2.9 \%$, respectively. The remaining conifers decreased in frequency and dominance, especially red and white pines, two species that almost disappeared from the region (Table 1). At the cell scale (Figure 3), pattern of changes in relative frequency were rather uniform for most increasing (jack pine, maple, and poplar) or decreasing taxa (spruce, yellow birch, white cedar, larch, and other pines), except white birch and balsam fir which displayed patchy patterns of increases and decreases.

\section{Landscape Tree Assemblages}

Cluster analysis revealed considerable reorganization of tree assemblages across the study area during the last century (Figure 4). Clusters 1, 2, and 4 were the most widespread before settlement ( $83 \%$ of all cells) and were dominated by spruce, balsam fir and white birch (Figure 4A). Although similar in overall composition, these three clusters differ from each other on some points. In cluster 2 , spruce, balsam fir and white birch dominate largely over the remaining taxa. Cluster 1 shows a more diverse composition and is the cluster with the largest mean relative frequency of yellow birch (16\%), white cedar (7\%), and other pines (5\%) (Figure 4B). Cluster 4 contains noticeably more poplar and jack pine than clusters 1 and 2. In contrast to pre-settlement times, the present-day landscape is dominated by cluster 3 (36\% of all cells) with high relative frequency of white birch (24\%), poplar (19\%), and maple (8\%), and the lowest relative frequency of spruce (16\%) among clusters. This cluster was almost absent during pre-settlement times (14 cells) and became widespread throughout the study area. The jack pine cluster (5) also increased in frequency, mostly on the plains, while clusters 1 and 2 have been completely excluded from the plains and confined to uplands at the periphery of the study area (Figure 4A).

The transition diagram (Figure 4C) and the PCA (Figure 5) provide insights into trajectories of tree assemblages between time periods. Most cells belonging to clusters 1 and 2 in presettlement times shifted to clusters 3 and 4 in the present-day, which are characterized by high poplar relative frequency. Cluster 3 has remained ubiquitous across environmental gradients, although slightly more associated with the uplands today. Conversely, cells from clusters 1 and 2 are now much more associated with till deposits, steep slopes and high elevations than they were during pre-settlement times. The jack pine cluster gained cells almost exclusively from cluster 4, where jack pine was already present (Figure 4B), and strengthened its relationship with sandy deposits. In contrast, cluster 4 exchanged many cells with other clusters and became less strongly associated with the surface deposits of the plains.

\section{DISCUSSION}

\section{Pre-settlement Tree Assemblages}

The landscape tree assemblage dominated by spruce, balsam fir and white birch (cluster 2) was the most common before settlement and was mostly associated with the uplands of the boreal zone. Since the mean relative frequency was high for balsam fir, and very low for poplar and jack pine, the disturbance regime governing this assemblage was probably characterized by forest openings created by windthrow and spruce budworm outbreaks (Kneeshaw and Bergeron, 1999; Bergeron, 2000; Lesieur et al., 2002), along with occasional fires. Recent research in the region supports our results and shows low fire activity on uplands during the preindustrial era (Couillard et al., 2013; Boucher et al., 2014). Southeast of Lake St-Jean and along the Saguenay River, the spruce-fir-white birch assemblage was often accompanied by more temperate species, such as yellow birch, white cedar and red and white pines (cluster 1). This was probably due to the more temperate conditions associated with the Saguenay River valley, where low elevations create milder 


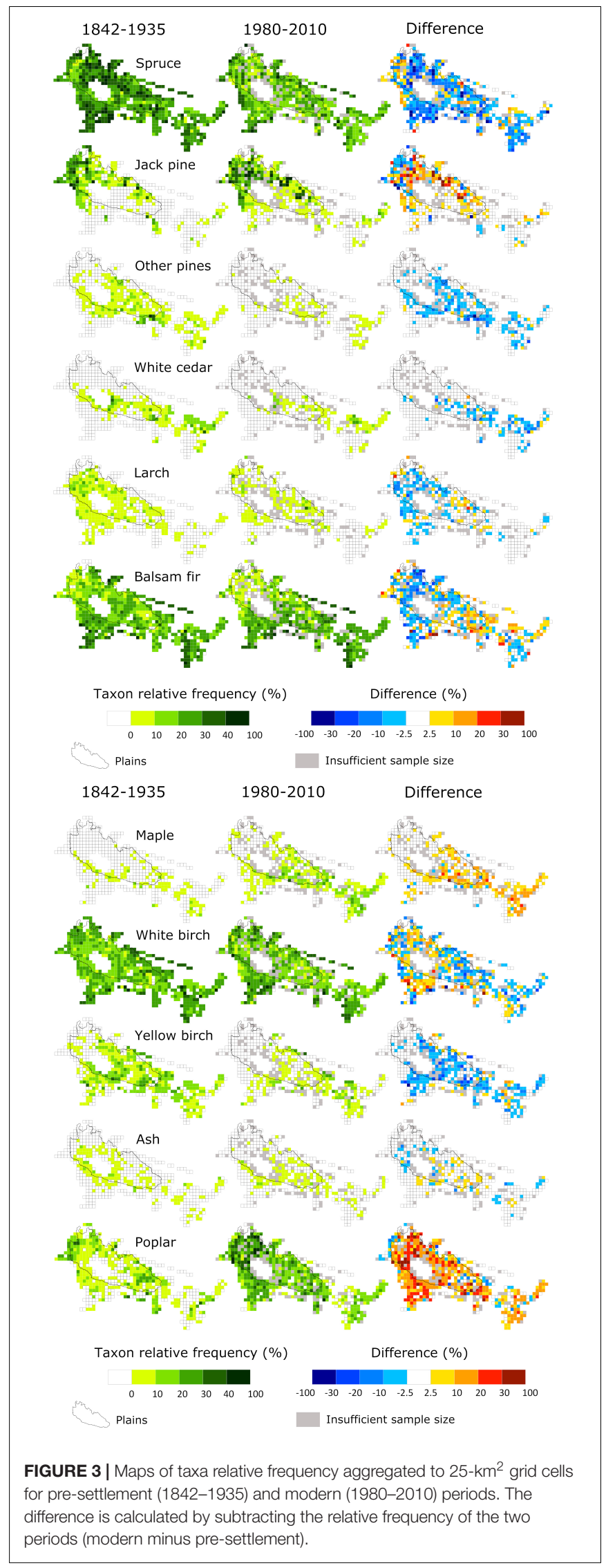

winters and warmer summers compared to uplands (Girard and Perron, 1989; Audet et al., 2012).

Two fire-adapted tree assemblages (clusters 4 and 5) prevailed north and west of lake St-Jean. The presence of trembling aspen (Populous tremuloïdes, Supplementary Figure S5) and jack pine in these clusters suggests that fires were frequent before settlement. Fire was probably more influential in the jack pine cluster (5) considering the very low relative frequency of balsam fir, a fire-sensitive species (Frank, 1990), along with the high relative frequency of jack pine, often considered as fire-dependant (Burns and Honkala, 1990). Moreover, the fireadapted black spruce (Viereck and Johnston, 1990) was probably an important species in cluster 5 , as modern plots show a very low present-day frequency of white spruce compared to black spruce (Supplementary Figure S5 and Supplementary Table S1). This sector has few firebreaks as its topography is flat and lake abundance is low. This may have facilitated the spread of fires (Lynch et al., 2014), thus promoting the presence of jack pine, especially on poor and well-drained sandy deposits where fires are more likely to occur (Mansuy et al., 2010).

Innu people may also have influenced fire activity in the SLSTJ region, as did other First Nations in southern Québec (Blarquez et al., 2018), Labrador (Oberndorfer, 2020), Ontario (Munoz and Gajewski, 2010), and United States (Roos et al., 2018; Abrams and Nowacki, 2019). For example, Innu people possibly used fire to manage wild animal populations, to clear small patches to set up camps, to stimulate productivity of berry patches or the recruitment of white birch, which was essential for the construction of dwellings and canoes (Day, 1953; Lewis, 1980; Lewis and Ferguson, 1988; Girard and Perron, 1989; Williams, 2000; Oberndorfer, 2020). Although mostly of local importance (Russel, 1983; Oswald et al., 2020), these fires may have occasionally escaped and affected forest composition on large areas on the SLSTJ's plains, where fire-adapted species were frequent before European settlement.

\section{Changes in Forest Composition}

Our results show an increase of fast-growing and earlysuccessional species in poplar, maple and jack pine since presettlement times, to the detriment of long-lived, late-successional species such as spruce, yellow birch, cedar, and other pines (red and white pines). This trend has been widely documented across temperate and boreal zones of eastern North America as a consequence of human activities (Friedman and Reich, 2005; Pinto et al., 2008; Hanberry et al., 2013; Thompson et al., 2013; Danneyrolles et al., 2016; Boucher et al., 2017; Terrail et al., 2019).

Although the effects of climate change cannot be discarded (Pederson et al., 2015; Boisvert-Marsh et al., 2019), anthropogenic fire disturbance most likely played an important role in these changes. During the settlement period, settlers cleared the forest and usually burnt the logging waste to facilitate the establishment of agriculture (Blanchet, 2003). This operation was often sloppy, and settlers did not take the necessary precautions to prevent fire from spreading to nearby forests. Aided by drought and high winds, these fires could have spread over large areas (Boucher et al., 2014), as it was the case in 1870 when a fire ignited by settlers, west of Lake St-Jean, escalated into a major conflagration 


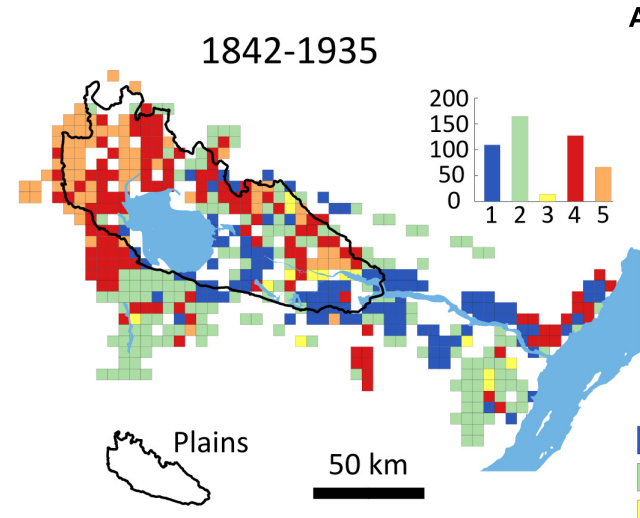

\section{B Cluster composition}

\begin{tabular}{|c|c|c|c|c|c|c|}
\hline & 1 & & 2 & 3 & 4 & 5 \\
\hline Taxa & $\begin{array}{llll}0 & 10 & 20 & 30\end{array}$ & 010 & 203040 & $\begin{array}{llll}0 & 10 & 20 & 30\end{array}$ & $\begin{array}{lllll}0 & 10 & 20 & 30 & 40\end{array}$ & $\begin{array}{lllll}0 & 10 & 20 & 30 & 40\end{array}$ \\
\hline Spruce & - & & - & $\square$ & - & + \\
\hline Balsam fir & $\square$ & 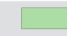 & $\square$ & $\square$ & L & $\square$ \\
\hline White cedar & $r$ & t & & - & - & t \\
\hline Jack pine & t & t & & Z & $\square$ & 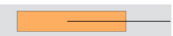 \\
\hline Other pines & E & - & & - & I & t \\
\hline Larch & ト & 7 & & t & + & E \\
\hline White birch & 1 & 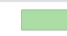 & $\square$ & $\square$ & $\square$ & $\square$ \\
\hline Yellow birch & 1 & $\square$ & & 7 & 1 & t \\
\hline Poplar & E- & - & & $\square$ & $\square$ & $\square$ \\
\hline Maple & E & $t$ & & $\square$ & 1 & t \\
\hline Ash & - & t & & - & t & t \\
\hline
\end{tabular}

C Transition

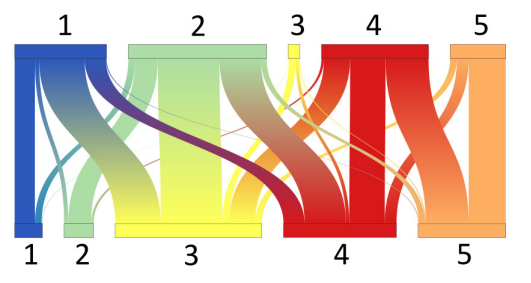

FIGURE 4 | Landscape tree assemblages identified by hierarchical clustering of the $25-\mathrm{km}^{2}$ grid cells. (A) Maps of the clusters for the two time periods with histograms showing the number of cells in each cluster; (B) Table of cluster composition showing taxon mean relative frequency and standard deviation (bars); (C) Transition among clusters from pre-settlement (top) to modern (bottom) periods. The width of each box is proportional to the corresponding number of cells.

that ran over $120 \mathrm{~km}$ on the plains (Blanchet, 2003). Despite the enactment of a fire exclusion policy enforced by law in 1870 (Blanchet, 2003), subsequent governmental reports indicated that more than $67 \%$ of the forest fires were anthropogenic between 1906 and 1941, with 6\% caused by lightning, and 27\% from unknown origin (Québec, 1906-1941). High fire activity during the settlement period has been documented in several regions of North America (Weir and Johnson, 1998; Lefort et al., 2003; Hessl et al., 2011; Stambaugh et al., 2018; Terrail et al., 2020) and Scandinavia (Lehtonen and Huttunen, 1997; Groven and Niklasson, 2005). While severe fire weather conditions may have facilitated fire spread (Lefort et al., 2003; Grenier et al., 2005), anthropogenic ignition appears to be the main factor explaining the high fire activity during the settlement period (Niklasson and Granström, 2000; Blanchet, 2003; Boucher et al., 2014; Terrail et al., 2020).

Consequently, pyrophile tree species benefited the most from the European settlement in the SLSTJ region. Trembling aspen (Supplementary Figure S5) increased throughout the study area and is now the most dominant tree. This species is known to quickly invade burned sites, both through wind-dispersed seeds and suckers (Perala, 1990; Bergeron and Charron, 1994;
Bergeron, 2000; Fortin, 2008). As for jack pine, with its serotinous cones and early sexual maturity, it probably took advantage of successive fires to outcompete fire-sensitive species such as white spruce, balsam fir and larch (Larix laricina) (Burns and Honkala, 1990), especially on sandy deposits where it was already present and highly competitive (Greene et al., 2004; Mansuy et al., 2010). In fact, the increase of jack pine is a particularity of our study area because this taxon has generally decreased at the temperateboreal ecotone since pre-settlement times (Radeloff et al., 1999; Friedman and Reich, 2005; Pinto et al., 2008; Hanberry et al., 2013). In these regions, fire suppression and logging have been identified as the main drivers of forest composition changes, whereas in SLSTJ the increase in jack pine is most likely related to high fire activity during the settlement period. Red maple is another taxon that may have benefited from fire disturbance. Red maple is by far the most abundant maple species in the study area today (Supplementary Figure S5) and is known to be favored by fire at its northern range limit (Zhang et al., 2015).

Logging has been identified as the main cause of vegetation change since pre-settlement in many regions at the temperateboreal transition (Jackson et al., 2000; Friedman and Reich, 2005; Boucher et al., 2006; Dupuis et al., 2011; Hanberry et al., 2013) 


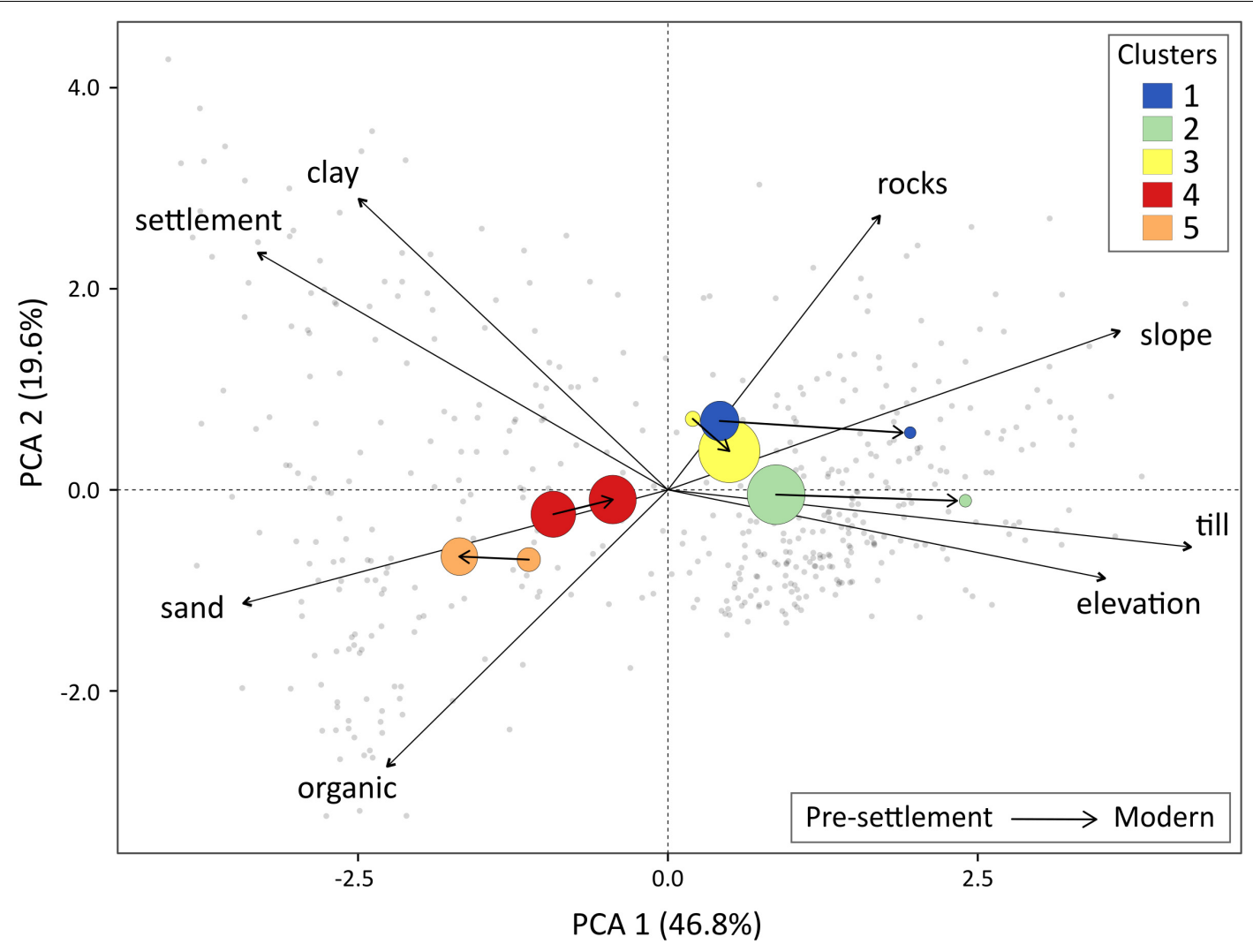

FIGURE 5 | Principal component analysis (PCA) where axes 1 and 2 explain $46.8 \%$ and $19.6 \%$ of the environmental variability, respectively. Biplot shows cell scores (grey dots), correlations of environmental variables with axes 1 and 2, and clusters (circles) for both time periods as the centroids of the corresponding cell scores. Circles size is proportional to the corresponding number of cells in each cluster. Arrows between clusters show the transition from pre-settlement to modern periods. PCA1 mainly represents the plains on the left, where clay and sandy deposits are predominant, and the uplands on the right, where glacial till is abundant and settlement is absent. PCA2 is more associated with soil texture and reflects more subtle differences among cells.

and was probably an additional causal factor of forest changes in SLSTJ. In a first phase, selective cutting that started with settlement quickly depleted red and white pines and then white spruce, which became the principal species harvested during the 19th century (Girard and Perron, 1989). During the second phase, extensive clear-cut logging during the 20th century targeted all conifers. In addition to directly decreasing conifer dominance, large openings in the canopy may have favored the invasion of fast-growing species such as poplars, white birch and red maple (Harvey and Bergeron, 1989; Fei and Steiner, 2009; Laquerre et al., 2009). Logging and fire may also have acted synergistically to favor disturbance-adapted species (Boucher et al., 2017).

The variable trend of balsam fir abundance in our study area concur with previous studies as its decline (Jackson et al., 2000; Danneyrolles et al., 2016), its stability (Pinto et al., 2008; Terrail et al., 2019), or its increase (Friedman and Reich, 2005; Hanberry et al., 2013) have all been reported. The increase of balsam fir's relative frequency in the eastern sector of our study area can be explained by the maintenance of a large seedlings bank, which allows the species to rapidly re-establish following clear-cuts (Archambault et al., 2006; Prévost, 2008) or spruce budworm outbreaks (Baskerville, 1975; Blais, 1983). However, the sensitivity of balsam fir to fire probably led to its decline in the western part of our study area, where the fireadapted jack pine, aspen and white birch (Burns and Honkala, 1990) greatly increased. Similarly, we observed increasing and decreasing trends of white birch abundance, paralleling other studies in boreal and temperate-boreal transition forests where the species was abundant prior to settlement [Friedman and Reich, 2005; Danneyrolles et al., 2019 (see Supplementary Figure S2), Marchais et al., 2020]. Although white birch in our study area may have benefited from fire, and from openings created by spruce budworm outbreaks and logging, it may have been outcompeted by aspen on burnt sites (Terrail et al., 2020), and likely affected by episodes of dieback during the 20th century (Pomerleau, 1991; Auclair et al., 1997).

Although logging and repeated fires have most likely played a role in the exclusion of the spruce-fir-white birch assemblages (clusters 1 and 2) from the plains, land cover change was probably a major contributing factor as urban and agricultural areas now occupy $32 \%$ of the plains' surface (Figure 2C). Indeed, most of the plains' $25-\mathrm{km}^{2}$ cells discarded from the analyses due to the lack of modern plots have had on average $62 \%$ of their 
surface transformed to agricultural or urban land uses and were dominated by clusters 1 and 2 before settlement (Supplementary Figure S2). Residual cells of these clusters now occur chiefly on the uplands or close to the Saguenay River, where human population density is low and agriculture not developed. Thus, several cells of clusters 1 and 2 on the plains have been either lost to land-use change (agriculture, urbanization) or replaced by new tree assemblages (clusters 3 and 4 ) better adapted to human disturbances (fire, logging, and land clearing).

\section{Forest Management Implications}

In light of our results, strict ecosystem-based forest management in SLSTJ should aim to increase spruce frequency and dominance, and decrease disturbance-adapted (fast-growing, shade intolerant) species such as aspen and red maple. Since spruce is still present throughout the territory, conversion from aspen to coniferous stands through natural succession or partial cutting (Brais et al., 2019; Prévost and Charette, 2019) are potential management solutions, although landscape fragmentation and continuing forest harvesting are likely to favor the retention of shade intolerant species such as white birch and aspen (Fortin, 2008). Thus, tree planting programs guided by past substrate preferences may be needed for spruce as well as for restoring the less abundant yellow birch, pines (red and white) and cedar to higher frequency and dominance levels.

However, in light of anticipated climate change, along with current uncertainties on future disturbance rates (Bergeron et al., 2006, 2010; Boulanger et al., 2019) and fire suppression effectiveness (Wotton et al., 2017), more flexible management options may be needed. Pre-settlement forest composition can provides targets to maintain or restore functional diversity and resilience (Boulanger et al., 2019). For example, species sensitivity or adaptations to disturbances can be considered in order to maintain functionally diverse and spatially heterogeneous stands and landscapes similar to pre-settlement conditions (Danneyrolles et al., 2020). Yet, it should be noted that our study only provides reference conditions for the period just before

\section{REFERENCES}

Abrams, M. D., and Nowacki, G. J. (2019). Global change impacts on forest and fire dynamics using paleoecology and tree census data for eastern North America. Ann. For. Sci. 76:8. doi: 10.1007/s13595-018-0790-y

Archambault, L., Delisle, C., Larocque, G. R., Sirois, L., and Belleau, P. (2006). Fifty years of forest dynamics following diameter-limit cuttings in balsam fir-yellow birch stands of the Lower St. Lawrence region, Québec. Can. J. For. Res. 36, 2745-2755. doi: 10.1139/x06-179

Auclair, A. N. D., Eglinton, P. D., and Minnumeyer, S. L. (1997). Principal forest dieback episodes in northern hardwoods: development of numeric indices of areal extent and severity. Water Air Soil Pollut. 93, 175-198. doi: 10.1007/ bf02404755

Audet, R., Côté, H., Bachand, D., and Mailhot, A. (2012). Atlas Agroclimatique du Québec : Évaluation des Opportunités et Des Risques Agroclimatiques Dans un Climat en Évolution. Ouranos, Rapport de Recherche (R1518). Québec, QC: INRS.

Baskerville, G. L. (1975). Spruce budworm: super silviculturist. For. Chron. 51, 138-140. doi: $10.5558 / \mathrm{tfc} 51138-4$

Bergeron, Y. (2000). Species and stand dynamics in the mixed woods of Quebec's southern boreal forest. Ecology 81, 1500-1516. doi: 10.1890/0012-9658(2000) $081[1500$ :sasdit]2.0.co;2 the European settlement, and that longer paleoecological records should also be considered to identify a wider range of vegetation targets for future climate trends and disturbance regimes.

\section{DATA AVAILABILITY STATEMENT}

The datasets generated for this study are available on request to the corresponding author.

\section{AUTHOR CONTRIBUTIONS}

$\mathrm{SD}, \mathrm{DA}$, and VD designed the study and methodology. SD extracted and compiled the data. SD analyzed the data with the help of VD. SD wrote the manuscript with substantial inputs from DA, YB, VD, and JL. All authors contributed to the article and approved the submitted version.

\section{FUNDING}

This study was financed by the Québec's Ministère des Forêts, de la Faune et des Parcs (project no. 142332152-B).

\section{ACKNOWLEDGMENTS}

We thank two reviewers for their constructive comments, which greatly improved the first version of the manuscript. We also thank Rachel Bouserhal for English revision.

\section{SUPPLEMENTARY MATERIAL}

The Supplementary Material for this article can be found online at: https://www.frontiersin.org/articles/10.3389/fevo.2020.00257/ full\#supplementary-material

Bergeron, Y., and Charron, D. (1994). Postfire stand dynamics in a southern boreal forest (Québec): a dendroecological approach. Ecoscience 1, 173-184. doi: 10.1080/11956860.1994.11682241

Bergeron, Y., Cyr, D., Drever, C. R., Flannigan, M., Gauthier, S., Kneeshaw, D., et al. (2006). Past, current, and future fire frequencies in Quebec's commercial forests: implications for the cumulative effects of harvesting and fire on ageclass structure and natural disturbance-based management. Can. J. For. Res. 36, 2737-2744. doi: 10.1139/x06-177

Bergeron, Y., Cyr, D., Girardin, M. P., and Carcaillet, C. (2010). Will climate change drive 21st century burn rates in Canadian boreal forest outside of its natural variability: collating global climate model experiments with sedimentary charcoal data. Int. J. Wildland Fire 19, 1127-1139.

Blais, J. R. (1983). Trends in the frequency, extent, and severity of spruce budworm outbreaks in eastern Canada. Can. J. For. Res. 13, 539-547. doi: 10.1139/ $\mathrm{x} 83-079$

Blanchet, P. (2003). Feux de Forêt: L'histoire d'une Guerre. Montréal, CA: Trait d'union.

Blarquez, O., Talbot, J., Paillard, J., Lapointe-Elmrabti, L., Pelletier, N., and Gates St-Pierre, C. (2018). Late Holocene influence of societies on the fire regime in southern Québec temperate forests. Quat. Sci. Rev. 180, 63-74. doi: 10.1016/j. quascirev.2017.11.022 
Boisvert-Marsh, L., Périé, C., and de Blois, S. (2019). Divergent responses to climate change and disturbance drive recruitment patterns underlying latitudinal shifts of tree species. J. Ecol. 107, 1956-1969. doi: 10.1111/1365-2745. 13149

Boucher, Y., Arseneault, D., and Sirois, L. (2006). Logging-induced change (19302002) of a preindustrial landscape at the northern range limit of northern hardwoods, eastern Canada. Can. J. For. Res. 36, 505-517. doi: 10.1139/ $\mathrm{x} 05-252$

Boucher, Y., Arseneault, D., Sirois, L., and Blais, L. (2009). Logging pattern and landscape changes over the last century at the boreal and deciduous forest transition in eastern Canada. Landsc. Ecol. 24, 171-184. doi: 10.1007/s10980008-9294-8

Boucher, Y., Auger, I., Noël, J., Grondin, P., and Arseneault, D. (2017). Fire is a stronger driver of forest composition than logging in the boreal forest of eastern Canada. J. Veg. Sci. 28, 57-68. doi: 10.1111/jvs.12466

Boucher, Y., Grondin, P., and Auger, I. (2014). Land use history (1840-2005) and physiography as determinants of southern boreal forests. Landsc. Ecol. 29, 437-450. doi: 10.1007/s10980-013-9974-x

Boulanger, Y., Arseneault, D., Boucher, Y., Gauthier, S., Cyr, D., Taylor, A., et al. (2019). Climate change will affect the ability of forest management to reduce gaps between current and presettlement forest composition in southeastern Canada. Landsc. Ecol. 34, 159-174. doi: 10.1007/s10980-0180761-6

Brais, S., Harvey, B. D., and Bose, A. K. (2019). Stem-and stand-level growth and mortality following partial cutting in eastern boreal poplar white spruce stands. Can. J. For. Res. 49, 463-470. doi: 10.1139/cjfr-20180177

Brice, M., Cazelles, K., Legendre, P., and Fortin, M.-J. (2019). Disturbances amplify tree community responses to climate change in the temperateboreal ecotone. Glob. Ecol. Biogeogr. 28, 1668-1681. doi: 10.1111/geb. 12971

Brice, M.-H., Vissault, S., Vieira, W., Gravel, D., Legendre, P., and Fortin, M.J. (2020). Moderate disturbances accelerate forest transition dynamics under climate change in the temperate-boreal ecotone of eastern North America. Glob. Change Biol. 26, 4418-4435. doi: 10.1111/gcb.15143

Burns, R. M., and Honkala, B. H. (1990). "Silvics of North America: l. Conifers, 2. Hardwoods," in Agriculture Handbook 654, eds R. M. Burns and B. H. Honkala (Washington, DC: United States Department of Agriculture, Forest Service).

Couillard, P.-L., Payette, S., and Grondin, P. (2013). Long-term impact of fire on high-altitude balsam fir (Abies balsamea) forests in south-central Quebec deduced from soil charcoal. Can. J. For. Res. 43, 188-199. doi: 10.1139/cjfr2012-0414

Danneyrolles, V., Arseneault, D., and Bergeron, Y. (2016). Preindustrial landscape composition patterns and post-industrial changes at the temperate-boreal forest interface in western Quebec, CA. J. Veg. Sci. 27, 470-481. doi: 10.1111/jvs. 12373

Danneyrolles, V., Arseneault, D., and Bergeron, Y. (2018). Anthropogenic disturbances strengthened tree community-environment relationships at the temperate-boreal interface. Landsc. Ecol. 33, 213-224. doi: 10.1007/s10980-0170591-y

Danneyrolles, V., Dupuis, S., Fortin, G., Leroyer, M., de Römer, A., Terrail, R., et al. (2019). Stronger influence of anthropogenic disturbance than climate change on century-scale compositional changes in northern forests. Nat. Commun. 10:1265. doi: 10.1038/s41467-019-09265-z

Danneyrolles, V., Vellend, M., Dupuis, S., Boucher, Y., Laflamme, J., Bergeron, Y., et al. (2020). Scale-dependent changes in tree diversity over more than a century in eastern Canada: landscape diversification and regional homogenisation. J. Ecol. doi: 10.1111/1365-2745.13474

Day, G. M. (1953). The Indian as an ecological factor in the northeastern forest. Ecology 34, 329-346. doi: 10.2307/1930900

Dupuis, S., Arseneault, D., and Sirois, L. (2011). Change from pre-settlement to present-day forest composition reconstructed from early land survey records in eastern Québec, Canada. J. Veg. Sci. 22, 564-575. doi: 10.1111/j.1654-1103. 2011.01282.x

Elson, J. A. (1969). Late quaternary marine submergence of Quebec. Revue de Géographie de Montréal 23, 247-258.
Environment Climate Change Canada (2019). 1981-2010 Canadian Climate Normals. Available online at: http://climate.weather.gc.ca/climate_normals/ index_e.html (accessed March 26, 2020).

Erni, S., Wang, X., Taylor, S., Boulanger, Y., Swystun, T., Flannigan, M., et al. (2020). Developing a two-level fire regime zonation system for Canada. Can. J. For. Res. 50, 259-273. doi: 10.1139/cjfr-2019-0191

Fei, S., and Steiner, K. C. (2009). Rapid capture of growing space by red maple. Can. J. For. Res. 36, 1444-1452. doi: 10.1139/X09-065

Fisichelli, N. A., Frelich, L. E., and Reich, P. B. (2014). Temperate tree expansion into adjacent boreal forest patches facilitated by warmer temperatures. Ecography 37, 152-161. doi: 10.1111/j.1600-0587.2013.00 197.x

Fortin, G. (2018). Transformation de la Composition de la Forêt de la Péninsule Gaspésienne au Cours du XXe Siècle. Dissertation. Rimouski, QC: Université du Québec à Rimouski.

Fortin, S. (2008). Expansion Postcoloniale du Tremble (Populus tremuloides) Dans le Bassin de la Rivière York, en Gaspésie. Dissertation. Chicoutimi, QC: Université du Québec à Chicoutimi.

Foster, D. R., Motzkin, G., and Slater, B. (1998). Land-use history as long-term broad-scale disturbance: regional forest dynamics in central New England. Ecosystems 1, 96-119. doi: 10.1007/s100219900008

Frank, R. M. (1990). "Abies balsamea (L.) Mill. Balsam fir Silvics of North America: 1. Conifers," in Agricultural Handbook 654, eds R. M. Bums and B. H. Honkala (Washington, DC: U.S. Department of Agriculture, Forest Service), 26-47.

Friedman, S. K., and Reich, P. B. (2005). Regional legacies of logging: departure from presettlement forest conditions in northern Minnesota. Ecol. Appl. 15, 726-744. doi: 10.1890/04-0748

Gauthier, S., Vaillancourt, M.-A., Leduc, A., De Grandpre, L., Kneeshaw, D. D., Morin, H., et al. (2009). Ecosystem Management in the Boreal Forest. Québec, QC: Les Presses de l'Université du Québec.

Girard, C., and Perron, N. (1989). Histoire du Saguenay-Lac-Saint-Jean. Québec, QC: Institut Québécois de recherché sur la culture.

Greene, D. F., Noel, J., Bergeron, Y., Rousseau, M., and Gauthier, S. (2004). Recruitment of Picea mariana, Pinus banksiana, and populus tremuloides across a burn severity gradient following wildfire in the southern boreal forest of Quebec. Can. J. For. Res. 34, 1845-1857. doi: 10.1139/ x04-059

Grenier, D. J., Bergeron, Y., Kneeshaw, D., and Gauthier, S. (2005). Fire frequency for the transitional mixedwood forest of timiskaming, Quebec, Canada. Can. J. For. Res. 35, 656-666. doi: 10.1139/x05-005

Groven, R., and Niklasson, M. (2005). Anthropogenic impact on past and present fire regimes in a boreal forest landscape of southeastern Norway. Can. J. For. Res. 35, 2719-2726. doi: 10.1139/x05-186

Hanberry, B. B., Palik, B. J., and He, H. S. (2013). Winning and losing tree species of reassembly in Minnesota's mixed and broadleaf forests. PLoS One 8:e61709. doi: 10.1371/journal.pone.0061709

Harvey, B. D., and Bergeron, Y. (1989). Site patterns of natural regeneration following clear-cutting in northwestern Québec. Can. J. For. Res. 19, 1458-1469. doi: $10.1139 / x 89-222$

Hessl, A. E., Saladyga, T., Schuler, T., Clark, P., and Wixom, J. (2011). Fire history from three species on a central appalachian ridgetop. Can. J. For. Res. 41, 2031-2039. doi: 10.1139/x11-125

Jackson, S. M., Pinto, F., Malcolm, J. R., and Wilson, E. R. (2000). A comparison of pre-European settlement (1857) and current (1981-1995) forest composition in central Ontario. Can. J. For. Res. 30, 605-612. doi: 10.1139/ x99-242

Johnstone, J. F., Allen, C. D., Franklin, J. F., Frelich, L. E., Harvey, B. J., Higuera, P. E., et al. (2016). Changing disturbance regimes, ecological memory, and forest resilience. Front. Ecol. Environ. 14, 369-378. doi: 10.1002/fee. 1311

Kneeshaw, D. D., and Bergeron, Y. (1999). Spatial and temporal patterns of seedling and sapling recruitment within canopy gaps caused by spruce budworm. Ecoscience 6, 214-222. doi: 10.1080/11956860.1999.11682522

Landres, P. B., Morgan, P., and Swanson, F. J. (1999). Overview of the use of natural variability concepts in managing ecological systems. Ecol. Appl. 9, 1179-1188. doi: 10.1890/1051-0761(1999)009[1179:ootuon]2.0.co;2 
Langevin, É, and Plourde, N. (2018). Sept millénaires de navigation sur la rivière Pitchitaouichez (Saguenay). Sommaire des connaissances archéologiques du fjord du Saguenay. Nat. Can. 142, 19-35. doi: 10.7202/1047146ar

Laquerre, S., Leduc, A., and Harvey, B. D. (2009). Augmentation du couvert en peuplier faux-tremble dans les pessières noires du nord-ouest du Québec après coupe totale. Écoscience 16, 483-491. doi: 10.2980/16-4-3252

Lefort, P., Gauthier, S., and Bergeron, Y. (2003). The influence of fire weather and land use on the fire activity of the Lake Abitibi area, Eastern Canada. For. Sci. 49, 509-521.

Legendre, P., and Legendre, L. (2012). Numerical Ecology, 3rd Edn. Amsterdam: Elsevier Science.

Lehtonen, H., and Huttunen, P. (1997). History of forest fires in eastern Finland from the fifteenth century $\mathrm{AD}$ - The possible effects of slash-and-burn cultivation. Holocene 7, 223-228. doi: 10.1177/095968369700700210

Lesieur, D., Gauthier, S., and Bergeron, Y. (2002). Fire frequency and vegetation dynamics for the south-central boreal forest of Quebec, Canada. Can. J. For. Res. 32, 1996-2009. doi: 10.1139/x02-113

Lewis, H. T. (1980). Indian fires in spring: hunters and gatherers of the Canadian forest shaped their habitat with fire. Nat. Hist. 89, 82-83.

Lewis, H. T., and Ferguson, T. A. (1988). Yards, corridors, and mosaics: how to burn a boreal forest. Hum. Ecol. 16, 57-77. doi: 10.1007/bf01262026

Lorimer, C. G. (1977). The presettlement forest and natural disturbance cycle of northeastern Maine. Ecology 58, 139-148. doi: 10.2307/1935115

Lorimer, C. G. (2001). Historical and ecological roles of disturbance in eastern North American forests: 9,000 years of change. Wildl.fe Soc. B 29, 425-439.

Lynch, E. A., Calcote, R., Hotchkiss, S. C., and Tweiten, M. (2014). Presence of lakes and wetlands decreases resilience of jack pine ecosystems to late-Holocene climatic changes. Can. J. For. Res. 44, 1331-1343. doi: 10.1139/cjfr-2014-0107

Mansuy, N., Gauthier, S., Robitaille, A., and Bergeron, Y. (2010). The effects of surficial deposit-drainage combinations on spatial variations of fire cycles in the boreal forest of eastern Canada. Int. J. Wildl. Fire 19:1083. doi: 10.1139/ x2012-101

Marchais, M., Arseneault, D., and Bergeron, Y. (2020). Composition changes in the boreal mixedwood forest of western Quebec since Euro-Canadian settlement. Front. Ecol. Evol. 8:126. doi: 10.3389/fevo.2020.00126

Millar, C. I., and Stephenson, N. L. (2015). Temperate forest health in an era of emerging megadisturbance. Science 349, 823-826. doi: 10.1126/science.aaa9933

Ministère de l'Énergie et des Ressources Naturelles du Québec [MERN] (2007). Couche Hypsométrique à l'échelle 1/20 000. Available online at: https:// donneesquebec.ca (accessed 26 March 2020).

Ministère des Forêts, de la Faune et des Parcs secteur des forêts [MFFP] (2015). Normes de Stratifications Écoforestière. Quatrième Inventaire Écoforestier du Québec Méridional. Direction des Inventaires Forestiers. Quebec, QC: Gouvernement du Québec.

Ministère des Forêts, de la Faune et des Parcs secteur des forêts [MFFP] (2016). Placettes-Échantillons Temporaires. Normes D'inventaire Écoforestier. Direction des Inventaires Forestiers. Quebec, QC: Gouvernement du Québec.

Munoz, S. E., and Gajewski, K. (2010). Distinguishing prehistoric human influence on late-Holocene forests in southern Ontario, Canada. Holocene 20, 967-981. doi: 10.1177/0959683610362815

Niklasson, M., and Granström, A. (2000). Numbers and sizes of fires: longterm spatially explicit fire history in a Swedish boreal landscape. Ecology 81, 1484-1499. doi: 10.1890/0012-9658(2000)081[1484:nasofl]2.0.co;2

Nowacki, G. J., and Abrams, M. D. (2008). The demise of fire and "mesophication" of forests in the Eastern United States. BioScience 58, 123-138. doi: 10.1641/ B580207

Nowacki, G. J., and Abrams, M. D. (2015). Is climate an important driver of postEuropean vegetation change in the Eastern United States? Glob. Change Biol. 21, 314-334. doi: $10.1111 / \mathrm{gcb} .12663$

Oberndorfer, E. (2020). What the Blazes!? A people's history of fire in labrador. J. North Atl. 40, 1-16.

Oswald, W. W., Foster, D. R., Shuman, B. N., Chilton, E. S., Doucette, D. L., and Duranleau, D. L. (2020). Conservation implications of limited Native American impacts in pre-contact New England. Nat. Sustain. 3, 241-246. doi: 10.1038/ s41893-019-0466-0

Pederson, N., D’Amato, A. W., Dyer, J. M., Foster, D. R., Goldblum, D., Hart, et al. (2015). Climate remains an important driver of post-European vegetation change in the eastern United States. Glob. Change Biol. 21, 2105-2110. doi: 10.1111/gcb.12779

Perala, D. A. (1990). "Populus tremuloides Michx. Quaking aspen Silvics of North America: 2. Hardwoods," in Agricultural Handbook 654, eds R. M. Burns and B. H. Honkala (Washington, DC: U.S. Department of Agriculture, Forest Service), 555-569.

Pilon, V., and Payette, S. (2015). Sugar maple (Acer saccharum) forests at their northern distribution limit are recurrently impacted by fire. Can. J. For. Res. 45, 452-462. doi: 10.1139/cjfr-2014-0322

Pinto, F., Rornaniuk, S., and Ferguson, M. (2008). Changes to preindustrial forest tree composition in central and northeastern Ontario, Canada. Can. J. For. Res. 38, 1842-1854. doi: 10.1139/X08-034

Pomerleau, R. (1991). Experiments on the Causal Mechanisms of Dieback on Deciduous Forests in Québec, Information Report LAU-X-96. Sainte Foy, QC: Québec Region Canadian Forest Service.

Pouyez, C., Lavoie, Y., and Bouchard, G. (1983). Les Saguenayens : Introduction à L'histoire des Populations du Saguenay, XVIe-XXe siècles. Sillery, QC: Presses de l'Université du Québec.

Prévost, M. (2008). Effect of cutting intensity on microenvironmental conditions and regeneration dynamics in yellow birch-conifer stands. Can. J. For. Res. 38, 317-330. doi: 10.1139/X07-168

Prévost, M., and Charette, L. (2019). Shelterwood cutting in a boreal mixedwood stand: 5-year effects of the final cut on development of aspen suckers and released conifers. For. Chron. 95, 113-123.

Québec (1906-1941). Département des Terres et Forêts. Rapports sur la Protection des Forêts Dans la Province de Québec. Québec, CA: Documents de la Session.

R Core Team (2019). R: A language and Environment for Statistical Computing. Vienna: R Foundation for Statistical Computing.

Radeloff, V. C., Mladenoff, D. J., He, H. S., and Boyce, M. S. (1999). Forest landscape change in the northwestern Wisconsin pine barrens from preEuropean settlement to the present. Can. J. For. Res. 29, 1649-1659. doi: 10. 1139/x99-089

Robitaille, A., and Saucier, J.-P. (1998). Paysages Régionaux du Québec Méridional. Québec, QC: Publications du Québec.

Roos, C. I., Zedeno, M. N., Hollenback, K. L., and Erlick, M. M. H. (2018). Indigenous impacts on North American great plains fire regimes of the pas millennium. Proc. Natl. Acad. Sci. U.S.A. 115, 8143-8148. doi: 10.1073/pnas. 1805259115

Russel, E. W. B. (1983). Indian-set fires in the forests of the northeastern United States. Ecology 64, 78-88. doi: 10.2307/1937331

Schulte, L., and Mladenoff, D. J. (2001). The original US public land survey records: their use and limitations in reconstructing presettlement vegetation. J. For. 99, 5-10.

Schulte, L. A., Mladenoff, D. J., Crow, T. R., Merrick, L. C., and Cleland, D. T. (2007). Homogenization of northern U.S. Great Lakes forests due to land use. Landsc. Ecol. 22, 1089-1103. doi: 10.1007/s10980-007-9095-5

Scull, P. R., and Richardson, J. L. (2007). A method to use ranked timber observations to perform forest composition reconstruction from land survey data. Am. Midl. Nat. 158, 446-460. doi: 10.1674/0003-0031(2007)158[446: amturt]2.0.co;2

Simard, I., Morin, H., and Lavoie, C. (2006). A millennial-scale reconstruction of spruce budworm abundance in Saguenay, Québec, Canada. Holocene 16, 31-37. doi: 10.1191/0959683606hl904rp

Stambaugh, M. C., Marschall, J. M., Abadir, E. R., Jones, B. C., Brose, P. H., Dey, D. C., et al. (2018). Wave of fire: an anthropogenic signal in historical fire regimes across central Pennsylvania, USA. Ecosphere 9:e02222. doi: 10.1002/ ecs 2.2222

Terrail, R., Arseneault, D., Fortin, M.-J., Dupuis, S., and Boucher, Y. (2014). An early forest inventory indicates high accuracy of forest composition data in pre-settlement land survey records. J. Veg. Sci. 25, 691-702. doi: 10.1111/jvs. 12142

Terrail, R., Dupuis, S., Danneyrolles, V., Fortin, M.-J., Boucher, Y., and Arseneault, D. (2019). Reorganization of tree communities over the last century in the northern hardwoods of eastern Canada. Appl. Veg. Sci. 22, 474-483. doi: 10. 1111/avsc.12449

Terrail, R., Morin-Rivat, J., Lafontaine, G., Fortin, M.-J., and Arseneault, D. (2020). Effects of 20th-century settlement fires on landscape structure and forest 
composition in Eastern Québec, Canada. J. Veg. Sci. 31, 40-52. doi: 10.1111/jvs. 12832

Thomas-Van Gundy, M. A., Nowacki, G. J., Anderson, R. C., Bowles, M. L., Brugam, R. B., Pavlovic, N. B., et al. (2020). Visualizing the Ecological Importance of pre-Euro-American Settlement Fire across Three Midwestern Landscapes. Am. Midl. Nat. 183, 1-23.

Thompson, J. R., Carpenter, D. N., Cogbill, C. V., and Foster, D. R. (2013). Four centuries of change in northeastern United States forests. PLoS One 8:e72540. doi: 10.1371 /journal.pone. 0072540

Viereck, L. A., and Johnston, W. F. (1990). "Picea mariana (Mill) B.S.P. Black spruce Silvics of North America: 1. Conifers," in Agricultural Handbook 654, eds R. M. Burns and B. H. Honkala (Washington, DC: U.S. Department of Agriculture, Forest Service), 443-464.

Weir, J. M. H., and Johnson, E. A. (1998). Effects of escaped settlement fires and logging on forest composition in the mixedwood boreal forest. Can. J. For. Res. 28, 459-467. doi: 10.1139/x98-001

White, M., and Mladenoff, D. (1994). Old-growth forest landscape transitions from pre-European settlement to present. Landsc. Ecol. 9, 191-205. doi: 10.1007/ BF00134747

Whitney, G. G. (1994). From Coastal Wilderness to Fruited Plain: A History of Environmental Change in Temperate North America, 1500 to the Present. Cambridge: Cambridge University Press.
Williams, G. W. (2000). An introduction to aboriginal fire use in North America. Fire Manag. Today 60, 8-12.

Wotton, B. M., Flannigan, M. D., and Marshall, G. A. (2017). Potential climate change impacts on fire intensity and key wildfire suppression thresholds in Canada. Environ. Res. Lett. 12:095003. doi: 10.1088/1748-9326/ aa7e6e

Zhang, Y., Bergeron, Y., Zhao, X.-H., and Drobyshev, I. (2015). Stand history is more important than climate in controlling red maple (Acer rubrum L.) growth at its northern distribution limit in western Quebec, Canada. J. Plant. Ecol. 8, 368-379. doi: 10.1093/jpe/rtu029

Conflict of Interest: The authors declare that the research was conducted in the absence of any commercial or financial relationships that could be construed as a potential conflict of interest.

Copyright (c) 2020 Dupuis, Danneyrolles, Laflamme, Boucher and Arseneault. This is an open-access article distributed under the terms of the Creative Commons Attribution License (CC BY). The use, distribution or reproduction in other forums is permitted, provided the original author(s) and the copyright owner(s) are credited and that the original publication in this journal is cited, in accordance with accepted academic practice. No use, distribution or reproduction is permitted which does not comply with these terms. 